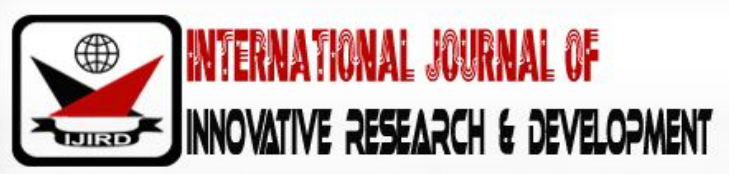

ISSN 2278 - 0211 (Online)

\section{Role of University of JOS Library Orientation Program in Curbing Library Anxiety}

\author{
Amando, Anita Ann \\ Assistant Librarian, Systems Unit, University of Jos Library, Nigeria \\ Dajab, NankyerDanjuma \\ Assistant Librarian, Acquisitions Unit, University of Jos Library, Nigeria \\ Bibot, NanlopSule \\ Assistant Librarian, Agricultural Sciences Librarian, University of Jos Library, Nigeria
}

\begin{abstract}
:
This paper is written in a bid to shed more light on the importance of library orientation and brings to the limelight the concept of library anxiety in the University of JOS Library. The researchers also base the research on personal experiences having worked in the library for a period of time and have observed that students (especially new students) have a phobia for using the library and its resources, resources that have been selected and acquired to aid them in learning and research.
\end{abstract}

Keywords: Library anxiety, orientation, academic library

\section{Introduction}

University of JOS is an academic institution situated in the North-Central region of Nigeria; it admits students from all works of life including foreigners. University of JOS library operates a creative learning space, provides electronic resources, open access resources, institutional repository as well as tailored resources gathered by subject librarians in collaboration with faculties and a host of other services with an aim to boost academic excellence. University of JOS library users consists of Students, faculty members, non-faculty members, visitors etc. The library carries out an orientation program for its newly admitted students at the start of every new academic session. Despite the resources and services provided, the library still witnesses low user patronage, non-utilization of its resources and services and students who never visit the library in the duration of their stay in the university. Academic libraries are also faced with the challenge of competing with advances in technology, information on the go and wherever you need it and a host of other distractions that provide its users with readily accessible information. However, it is expected that when students are introduced to orientation programs as they enter school, the library is able to market itself making it an indispensible part of student's life for the duration of their programs.

Orientation programs are organized to get students acquainted with the library and what it offers thereby making them masters in the use of the library as well as providing them with an overview on the resources and services the library offers and also on how to use the library as this will help to boost the confidence of its users making them life-long learners and helping them excel in their academics. This was also supported by (Rhoades and Hartsell, 2008) who posit that Orientation programs are designed to help students adjust to university life and ultimately improveretention rates, graduation rates, and grade point averages.

When students and faculty members do not attend orientation programs it makes them unsure of what to do in the library, do not know where to find the available resources and services the library provides, students and faculty members are at a loss on how to fit into the new library system which the library operates thereby keeping them away from visiting the library as well as not utilizing the library. This phenomenon has been termed as Library Anxiety by many scholars.

Academic libraries in Nigerian tertiary institutions according to (Isiaka and Olaide, 2013) are being confronted with the challenges of underutilization and apathy. These libraries are faced with daunting tasks of making their users aware of the numerous resources available, and how to encourage their usage. (Line, 1963 as cited in Yu, 2009) further asserted that "there is a general impression that students use libraries far less than they ought to". Most library staff shares this sentiment and the use of the library is an issue that is of constant concern to them.

For some students, Scientific and educational environments may give students the experience of an anxiety called "academic anxiety," which may be different for different people. The library is one of frequently named sources of anxiety in students (Erfanmanesh, 2011).(Battle, 2004; Onwuegbuzie, Jiao, \&Bostick, 2004; Jiao, Onwuegbuzie, \& Lichtenstein, 1996; Jiao, 
et al., 1996; Onwuegbuzie, et al., 2004; Kuhlthau, 1988, 1991; as cited in Lee, 2011) points out that a problem for some students is a psychological phenomenon called library anxiety (LA). There are a number of academic anxieties that can affect college students including math anxiety, test anxiety, information anxiety and library anxiety.

Library anxiety is defined as a state-based anxiety in which students experience uncomfortable feelings or emotions while in a library setting. Library anxiety is not uncommon for college students, who, when caught in a library-anxious moment, can feel tension, fear and a sense of helplessness. It can occur at any point within the library use or search process and can have a debilitating effect on a student's ability to complete assignments or develop proper information literacy skills.

(Hartman, 2009) asserts that "The transition from high school to college can be incredibly exciting and at the same time, terrifying for first-year college students. Moving into unfamiliar surroundings, making new friends, and living on their own can be an overwhelming experience. Along with these new lifestyle changes, college classes and coursework also contribute to even more anxiety; hence the need for Library orientation programs as students get enrolled. Librarians recognize that certain skills are needed to perform library college research and can help lessen this anxiety by showing the students how to effectively retrieve and evaluate the information that they need for their coursework. Similarly, (Anwar, AlKandari, and AlQallaf, 2004; Omran, 2001; as cited in SeyyedHosseini,Khosravi and Basirianjahromi, 2014) point out that Library anxiety is one of the main problematic matters in library and information science. Some researchers have founded that the main reason that makes a gap between users and librarians is the users' idea about dissatisfactory services in libraries. Students who have experienced a specific level of the library anxiety in library environment think that other students have enough competencies and desired skills to use library materials while they themselves have not. They also believe that asking a question in the library environment means that they are ignorant. These students do not pay enough attention to the library guides and signs; so they can't complete their search process.

Understanding a need for information is one thing as (Hartman, 2009) posits thatknowing where and how to find it efficiently is quite another. In helping to cultivate and refine students' research skills, librarians have a valuable role to play. They can assist students with finding additional information sources on virtually any topic, and, in general, they can help them find sources more quickly and easily. Librarians can also assist faculty by providing information literacy courses to their students and making recommendations for effective faculty-librarian collaboration.

\subsection{Statement of Problem}

University of JOS library caters to about 16,000 students, both undergraduate and postgraduate (Regular and Parttime). The objectives of the University of JOS Library naturally derive from those of the university it serves, the library exists to provide a variety of resources, book and non-book alike and ancillary services that support and extend the university's programmes of instruction and research (Ochai, 2010).The main goal of any academic library is to assist its students acquire information, utilize its resources and services and make them life-long learners. Library anxiety as a problem has hindered many potential users from accessing and visiting libraries and also stopping them from utilizing the resources and services the library provides. This situation poses a problem as library anxious students do not necessarily reach or tap into their potentials to achieve academic excellence.

(Jiao and Onwuegbuzie, 1999 as cited in Hartman, 2009) posits that for decades, librarians and library educators have observed that some students feel more comfortable while utilizing libraries than others do. Indeed, the idea that students vary in their levels of apprehension experienced when using academic libraries is not new. Yet, only recently have formal investigations been undertaken on the nature, etiology, characteristics, and consequences of this phenomenon. And, understandably, studies have shown that freshman exhibited the highest level of this documented anxiety. Based on this research, both faculty and librarians should learn how to recognize these "fear" characteristics and know how to ameliorate them by providing the appropriate anxiety-reducing interventions.

\section{Literature Review}

\subsection{Library Orientation}

Library orientation is a carefully, well-laid out instruction/ guide designed by librarians to educate its users on the use of the library, they resources and services they provide aimed at equipping it users have adequate knowledge about the library. It can also be seen as an avenue for fostering an interactive relationship between librarians and library users giving them confidence to approach librarians to help them in their research and educational needs.

Library orientation or user orientation towards the library has to do with adjusting the new library user to the library. It can also be seen as a way to ensure that library users can make use of library resources and services, adequately and to their own satisfaction; The Library Orientation program offers first year students an introduction to the library's resources and services, as well as information on study skills and academic integrity to help make the first year student experience successful. This means that the importance of library orientation upon entry cannot be over-emphasized(Janecatalla,2012). (Idiegbeyan-Ose and Ohaegbulam, 2014) see it as services rendered by the library to introduce the users to library resources and services in order to inculcate library use skills on them so as to save their time in library. While according to (Bem-Bura, 2015) Library orientation is an information and communication process which involves the totality of users' interaction with 
the library. It is a continuous process from the school level to libraries (national, public, academic, special, school libraries) which will add educational value to visits made to the libraries.

The aims of library orientation according to (Janecatalla, 2012) include but are not limited to the following:

- To help library users to feel at home in the library and trust the competency of the library staff;

- To enable library users to become skilled at finding information and thus foster feelings of confidence and independence.

- Library orientation makes library users aware of the library and the services it offers.

- Library orientation educates people regarding general use of the library,

(Janecatalla, 2012) states that Library orientation can be done in different ways:

- Informal library orientation- takes place when library workers do library orientation (or "user orientation" orientating them towards the library) continuously, on a one-to-one basis.

- Formal library orientation- Formal library orientation is when groups of people are introduced to the library in an organized way.

- Online library orientation- With the development of new technologies, library orientation is also possible via the Internet. Especially tertiary institutions like university libraries make use of this option.

The qualities required of librarians to do library orientation include: Personal qualities enthusiasm, the ability to communicate clearly and effectively, friendliness, patience and experience is very necessary in working with our public(Janecatalla, 2012).

One other importance of library orientation is due to the fact that most faculty direct students to the library to find the assigned information with little thought to the extent of the process involved in both locating this information and becoming information literate. Problems arise because: 1) most students have never been to the college library, 2) they often have absolutely no idea what to do once they are in the library, and 3) they are afraid, naturally enough, of making a complete idiot of themselves. (Hartman, 2009)

Librarians are therefore of the belief that library orientation is expected to increase user patronage in their respective libraries.

\subsection{Library Anxiety}

Library anxiety has been the target of researches in a number of countries, but only a few studies have been done in Nigeria. The term library anxiety was first coined by Constance Mellon in 1986. Mellon identified the recurrent themes of fear, confusion, a sense of being overpowered or lost, and a feeling of helplessness and dread, in the students' approach to having to use the library to conduct research (Carlile, 2007).Mellon decided to use the term "library anxiety" because of the phenomenon's close relationship to both math and test anxiety in process and affect. She believed that "it seemed logical to describe student's fear of the library as library anxiety and to consider treating it within the anxiety framework (Lee, 2011). Library anxiety according to (Mellon, 1986 as cited in Erfanmanesh, 2011) is defined as "the fear and negative feelings when using library, making ready for use and even when thinking about use of library". (Erfanmanesh, 2011) posits further that, library anxiety consists of any negative emotional symptoms such as fear, worry, uncertainty, perceiving lack of ability and efficiency, sense of loneliness, consternation, and etc. This phenomenon is a common thing among library users". However, a library orientation program can help to overcome such feelings.

In coining the term library anxiety, Constance Mellon used grounded-theory qualitative research methods primarily involving analysis of two years of student and instructor journals. From this, she determined that 75 to 85 percent of the students studied used terms of fear or anxiety in describing the library. Students in her study described themselves as library phobic and indicated that using the library was something they dreaded all semester. Students also described feelings of being lost or scared in the library, which they likened to a maze. Mellon identified four causes for student's feelings. Two were related to the physical space of the library - the size of the building and its layout- which they could not navigate. The other two causes were conceptual and related to the research process - or information literacy - itself. In addition to these students' anxious feelings about being in and using a library, Mellon also discovered that most believed that other students were more knowledgeable and competent in these skills which caused library-anxious students to feel shame and be unwilling to ask questions for fear of revealing their inadequacy and appearing stupid (Lee, 2011).

(Valentine, 1993; Kuhlthau, 1988, as cited in Mason, 2010) points out that in investigating undergraduate research behavior, Barbara Valentine found that unfamiliar library surroundings and resources were related to students' fear of undertaking a research project. She collected many comments from undergraduates, including many that were very similar to this one: "As a freshman I never came to the library except to study. It was kind of scary wondering how does this system work?". Undergraduates who are especially adverse to 'bothering' the librarians, consider themselves failures if they have to, and believe that other students will see them as failures as well. A major implication for students experiencing library anxiety is that they often exhibit low success levels when using academic libraries. Since the majority of undergraduate students will not ask for help, library staff must find other ways to reach out to them.(Mason,) points out that "New students are not confident in their abilities and are not fully prepared to meet the challenges of going to university without learning some new techniques to get them through. One problem is that they leave high school with little or no library skills to transfer to a postsecondary institution". 
(Bostick, 1993; Jiao, Onwuegbuzie, and Lichtenstein, 1996, as cited in Cleveland, 2001) points out that through further studies; library anxiety has been defined simply as "negative feelings toward using an academic library. More recently, more substance has been added to the library anxiety concept, explaining that students' uncomfortable feelings lead to cognitive, affective, physiological, and behavioral ramifications that interfere with their abilities to accomplish library tasks. In a paper written by (Carlile, 2007) she posits that "The feelings a student has about the library can influence whether or not they ask for help, how the)' approach their search for information, and how they respond to any obstacles they encounter in the library environment. In particular, the early stages of the information search process have been identified as producing feelings of uncertainty, confusion, frustration and doubt". (Jiao and Onwuegbuzie,2009) therefore stated that "students who received library instructions upon entering college were less likely to experience library anxiety. It is important for library instructors to be friendly and approachable. They should address the issue of library anxiety in a candid way so that students understand that they are not alone with this feeling. Library instructors should also encourage cooperative learning as a part of instruction programs".

\section{Recommendation/ Way Forward}

Having identified the importance of library orientation to students upon entering the university, the researchers have come up with the following recommendations:

- Library orientation programs should be made compulsory for all newly admitted students.

- Since University of JOS library operates a subject librarian set-up, subject librarians of the different faculties should carry out sensitization from time-to-time enlightening students on new developments in the library.

- A robust and concise library orientation manual should be designed by the library and updated frequently.

- Library orientation programs should be designed to be interactive, educative as well as entertaining.

- Librarians should be taught to be more welcoming and accommodating.

\section{Conclusion}

No studies have reflected analysis of library orientation and library anxiety as a problem in University of JOS Library. Library Orientation is seen as tool for curbing library anxiety. Therefore it is anticipated that findings and recommendations from this study will help improve service delivery, assisting students in libraries in general and specifically, University of JOS library.

\section{References}

i. Bem-Bura, M.D (2015). Students' Perception of Library Orientation Programme in Benue State University, Makurdi. International Journal of Innovative Research \& Development; Vol 4 Issue 3

ii. Carlile, H. (20007). The Implications of Library Anxiety for Academic Reference Services: A Review of the Literature. AARL; vol 38 no 2 pp.129 -147

iii. Cleveland, A.M. (2001). Reducing Library Anxiety in First-Year Students: Computer-Assisted Instruction vs. Bibliographic Instruction. Master's paper submitted to the faculty of the School of Information and Library Science of the University of North Carolina at Chapel Hill in partial fulfillment of the requirements for the degree of Master of Science in Library Science.

iv. Erfanmanesh, M. (2011). Use of Multidimensional Library Anxiety Scale on Education and Psychology Students in Iran. Library Philosophy and Practice

v. Hartman, S. (2009). Library fear deconstructed: overcoming Library Anxiety. 28th Annual Conference on the FirstYear Experience; Orlando, Florida

vi. Idiegbayay-Ose, J. and Ohaegbulam, H. (2014). Save library users' time, Ranganathan's fourth law of library science: Whyand how. Benue Journal of Library Management and Information Science 4 (1), 46-59

vii. Isiaka, A.O \&Olaide, I.A.(2013). Influence of Library Environments, Instructional Programs, and User-Librarian Collaborations on Library Use by Undergraduate Students in Nigeria. Chinese Librarianship: an International Electronic Journal; 35. www.iclc.us/ cliej/ cl35AI.pdf

viii. Janecatalla. (2012). Library orientation. Available at https:// www.slideshare.net/Janecatalla/ library-orientation14381347. Accessed on the 10 th of February, 20018

ix. Lee, S.W (2011). An Exploratory Case Study of Library Anxiety and Basic Skills English Students in a California Community College District. A dissertation submitted in partial satisfaction of the requirements for the degree Doctor of Education

x. Mason MK (2010) Myths Associated with Undergraduate Use of Academic Libraries: An Introduction. Available at:http:/ / www.moyak.com/ papers/ academic-library-anxiety

xi. SeyyedHosseini, S., Khosravi, A., \&BasirianJahromi, R. (2014).Investigating the relationship between library anxiety andemotionalintelligence.Webology;11(2),Article129. Available at: http:/ / www.webology.org/ 2014/v11n2/a129.pdf

xii. Yu, T. (2009). Library Anxiety and Library use: A Survey at Jinwen University of Science and Technology. 